\title{
Effect Characteristics of Satisfactory Quality Website Users Website E-Elang.Jatimprov Procurement of Goods / Services Provincial Government in East Java.
}

\author{
${ }^{1}$ Suharyanto, ${ }^{2}$ Kristinah, ${ }^{3}$ Dr. Priyono, MM. \\ ${ }^{1}$ Management Science Department, Faculty of Economics, PGRI Adi Buana University, Surabaya, \\ East Java of Indonesia. \\ ${ }^{2}$ civil servants East Java provincial government of East Java of Indonesia. \\ ${ }^{3}$ Management Science Department, Faculty of Economics, PGRI Adi Buana University, Surabaya \\ , East Java of Indonesia.
}

\begin{abstract}
A number of organizations / companies fail to effectively utilize the website, it shows that the website should be carefully designed to need to attract customers / users. The purpose of this study was to assess and to demonstrate empirically the effect of simultaneous characteristics of website quality on user satisfaction of elelang.jatimprov and to assess and demonstrate empirically the effect of partial characteristics of website quality on user satisfaction of e-auction website. jatimprov.. The method of analysis used in this study using Binary Logistic regression and Based on the results of multiple linear regression analysis, Content, Design, Accessibility and User Friendly affect user satisfaction of e-lelang.jatimprov East Java Province

Keyword: Website, e-auctions, Content, Design, Accessibility, User Friendly, User Satisfaction.
\end{abstract}

\section{Introduction}

The use of information technology intensively starting in 1990 has transformed an organization / company into an organization / enterprise digital. Organization / digital company is an organization that almost all digital her activity bridged (Kenneth C. Laudon, 2005:8). [1] The size of a market depends on the number of people who demonstrate a need for the product, the number of people who have the resources to attract others and willing to provide such resources (Philip Kotler, 1996: 7). [2] E-procurement or e-auction which was developed by the Government of East Java is a regional effort to streamline the bureaucratic work as mandated by the Act. E-procurement can be exercised if the goods and services required can be processed via the internet (Understanding the benefits of e-procurement, Andy Gueritz, Sixhills Consulting Ltd \& Author, 2001). [3] Eprocurement strategy can only be successful if the management of the procurement of goods / services immediately realized. A number of organizations / companies fail to effectively utilize the website, it shows that the website should be carefully designed to need to attract customers / users (Wan, 2002; siwasak_P.pdf). David Cunliffe (2002) [4], proved that good web design is not going to be detrimental to $50 \%$ of potential sales, and losing $40 \%$ of potential visitors to visit the website because of a negative experience. This claim is supported by Merwe (2000) [5], which states that the website does not provide support for a positive experience for customers will be left. And customers will be more than happy to shop (traditional) nearby. (Harold koontz dan cyrill odonnell 1997-99) [6]in their study, concluded that the user evaluate websites based on three criteria: Content, Content quality and Web design. The term content in a website related to information, features or services provided on the website. Content is obsolete (out of date) led to the failure of a website, Author websites usually accordance her views build their own website Furthermore it is said that the website should be related to the specific user. Thus, if a user gets a good response on the website the user will visit the website again. Inter-net/website users prefer factual and accurate information. They will immediately leave a site if there is a tone of arrogance / inaccuracies in the information displayed (Morkes \& Nielsen, 1997). [7] Internet users prefer words / terms / symbols are easy to understand. The use proper spelling and simple it would be easier for the user understanding (Buhalis, 1996). [8] Internet users will visit the site to suit their needs Design a website is a very important component and determine the success of a website in a user's perception Goes on to say, a good design also considers the upload and download speeds. Glen Urban $(2006,24-29,10)[9]$, says that when an organization supports its customers, then the customers will also support the organization. In other words, to succeed, a company / organization must implement a variety of ways to meet customer needs. Content on this Website represent the ideas, purposes, and objectives of the organization in support services to its customers. Event marketing begins with attention focused on the user, by trying to understand what you can meet and attract the attention of the user / customer to the product / service. (ACME, 2003:14). [10]. 


\section{Conceptual Framework}

This study refers to the opinion Layla Hasan et al (2008) [11], which builds a theoretical framework to evaluate a website regardless of the type of services provided by the website. By Layla Hasan et al (2008), the framework (framework) can be used to evaluate various web sites.

The picture frame idea as follows

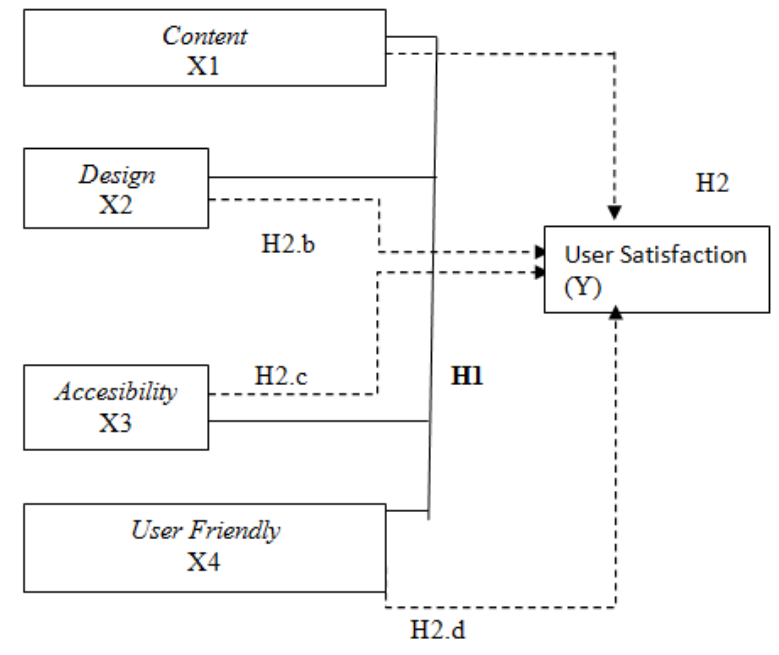

Figure 1 Framework Concept

\section{Methods.}

This study included in the census study, according Arikunto Suharsini (1996:115) [12]is the whole subject of the study population. If someone wants to examine all the elements that exist in the research area of research is the study population or also called the study population census. With reference to the opinion Nawami (1998:141), Nasir (1999:327) [13], and Sugiyono (2005:35) [14], the sample in this study are all bidders goods / services i Government of East Java, which is located in East Java. Questionnaire data collection method in this Provinsi study is to use the method personally administrated, questionnaire the researchers delivered questionnaires to the respondents themselves and take their own questionnaire. The ultimate goal that the questionnaire return rate can be maintained in a relatively short period of time. (Sekaran 2003:236). [15]Analysis techniques The method of analysis used in this study using Binary Logistic regression. Binary logistic regression analysis, by Singgih Santoso (2006) [16], aims to predict the value or amount of the dependent variable in the form of a binary variable with independent variables using data of known magnitude. In this research study was to Content, Design, Accessibility and User Friendly whether the effect on user satisfaction. The forms used binary logistic regression can be formulated:

where:

$$
\mathrm{Y}=\beta 0+\beta 1 \mathrm{X} 1++\beta 2 \mathrm{X} 2 \ldots \ldots \ldots . . \beta \mathrm{KXk}
$$

$\mathrm{Y}=$ user satisfaction (dependent variable)

$\beta 0=$ constant

$\beta 1, \beta 2, \ldots \ldots . . . \beta \mathrm{k}=$ coefficient of each independent variable

$\mathrm{X} 1, \mathrm{X} 2, \ldots \ldots . .$. Predictors to $\mathrm{Xk}=\mathrm{i}$.

\section{Results And Discussion.}

There are some plus and minus in the implementation of the full and partial. Full implementation makes the auction process can not be interfered with by anyone because all been done by the system, while the partial implementation, are still possible intervention to get the winner. In the application of partial, documents are sent electronically, but the evaluation still manually by considering the procurement of goods can be run in an honest and fair. The weakness of full implementation is the system can not detect the quality of the goods offered based on bid price only, so the quality of the goods supplied / generated is not entirely satisfactory.

Based on the results of non autocorrelation or Durbin-Watson DW values obtained for $1546(d=1546)$. Since $d$ $=1546<\mathrm{du}=1812$ then there is autocorrelation problem

Uji Heteroskedastisitas

Here is a picture no event heteroscedasticity 


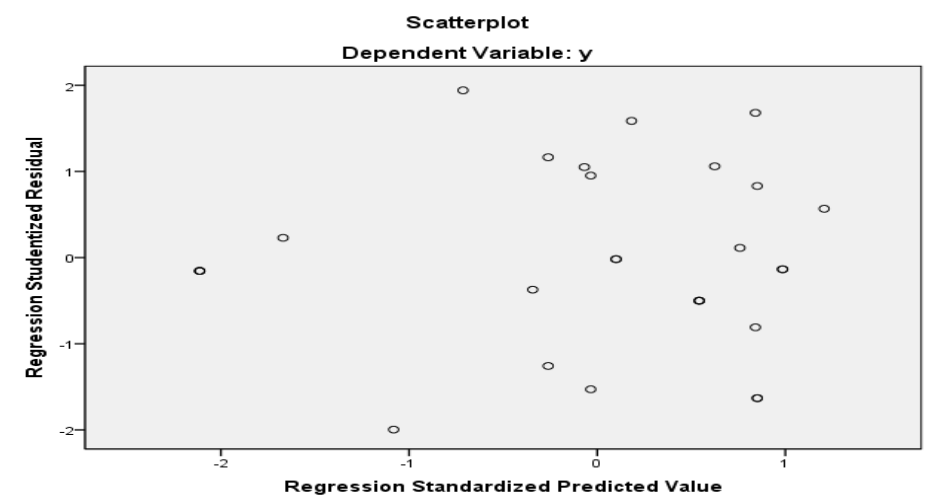

Figure 2

\section{Heteroskedastisitas}

Multiple Linear Regression Analysis. Based on the calculation results of data processing with the help of a computer program SPSS 19 for windows, the obtained linear regression equation in Table 1.

Table 1 Multiple Linear Regression Analysis Results.

\begin{tabular}{|c|c|c|c|c|}
\hline \multirow{2}{*}{ Model } & \multicolumn{2}{|c|}{ Unstandardized Coefisients } & \multirow{2}{*}{ T Hitung } & \multirow{2}{*}{ Sig } \\
\hline & B & Std. Error & & \\
\hline Constant & 9.193 & 3.401 & 2.703 & 0.013 \\
\hline Content (x1) & 0.539 & 0.820 & 0.657 & 0.0518 \\
\hline Design (x2) & -0.217 & 0.333 & -0.649 & 0.523 \\
\hline Acessibility (x3) & 0.414 & 0.429 & 0.966 & 0.344 \\
\hline User Friendly (x4) & -0.229 & 0.276 & -0.830 & 0.415 \\
\hline $\mathbf{R}$ & $=0.735$ & R Square & $=0.540$ & \\
\hline F Hitung & $=6.763$ & Sig & $=0.001$ & \\
\hline F tabel & $=(\mathrm{df}: 4 / 28 ; \alpha=0.05)=2.714$ & $\mathrm{~T}$ tabel & $=(\mathrm{df}: 4 / 28 ; \alpha=0.05)=2.048$ & \\
\hline
\end{tabular}

Sources: Appendix 3 (SPSS output)

Based on the calculation above, the linear regression equation is obtained as follows:

$Y=9.193+0.539$ X1 - 0.217 X2 + 0.414 X3 - 0.229X4.

Analysis of Correlation Coefficient and Coefficient of Determination.

Table 2. Sources: Appendix 3 (SPSS output).

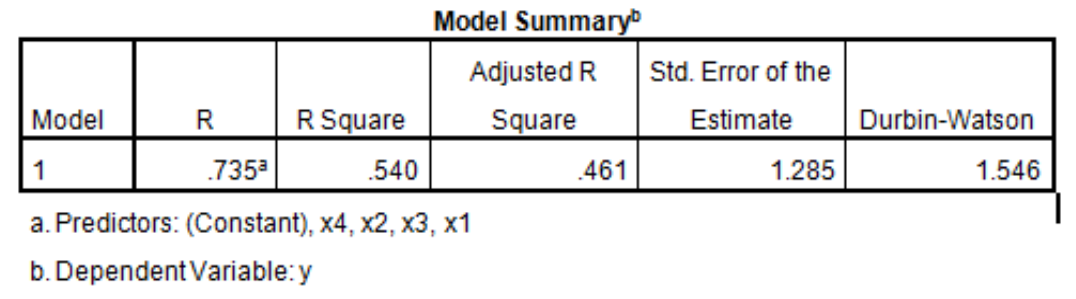

Appendix 3 (SPSS output).

\section{Hypothesis testing.}

In connection with the formulation of the problem and the proposed research hypotheses outlined earlier, it was explained that the variables that affect user satisfaction is Content (X1), Design (X2), Accessibility (X3), and User Friendly (X4). In this study, the dependent variable is User Experience, the variable Y.. The F (Simultaneous Test). Concurrent test ( $\mathrm{F}$ test) showed that all the independent variables consisting of Content (X1), Design (X2), Accessibility (X3), and User Friendly (X4) a significant effect on the dependent variable (User Experience).

Table 5.hasil Calculation Test F. 
刉

\begin{tabular}{|c|c|c|c|c|c|c|}
\hline \multicolumn{7}{|c|}{ ANOVA $^{\mathrm{b}}$} \\
\hline & & Sum of Squares & df & Mean Square & $\mathrm{F}$ & Sig. \\
\hline \multirow[t]{3}{*}{1} & Regression & 44.686 & 4 & \multirow{3}{*}{$\begin{array}{r}11.171 \\
+\quad 1.652 \\
+\quad\end{array}$} & \multirow[t]{3}{*}{6.763} & \multirow[t]{3}{*}{$.001^{\mathrm{a}}$} \\
\hline & Residual & 37.993 & 23 & & & \\
\hline & Total & 82.679 & 27 & & & \\
\hline
\end{tabular}

a. Predictors: (Constant), x4, x2, x3, x1

b. Dependent Variable: $y$

Sources: Appendix 3 (SPSS output).

The test:

1. hypothesis

Ho: $b 1=b 2=b 3=b 4=0$, meaning that the variables $\mathrm{X} 1, \mathrm{X} 2, \mathrm{X} 3, \mathrm{X} 4$ does not give effect to variable bound $(\mathrm{Y})$.

$\mathrm{H} 1: \mathrm{b} 1 \neq \neq \mathrm{b} 2 \mathrm{~b} 3 \mathrm{~b} 4 \neq \neq 0$, which means that the variables $\mathrm{X} 1, \mathrm{X} 2, \mathrm{X} 3, \mathrm{X} 4$ variable bound to give effect to $(\mathrm{Y})$.

2. The value

$\mathrm{F}$ table $=\mathrm{F} \alpha(\mathrm{df}$ regression, residual $\mathrm{df})=\mathrm{F} \alpha(\mathrm{k}, \mathrm{nk}-1)$

$\mathrm{F}$ table $=\mathrm{F} 0.05(4,23)=2.796$

3. Critical region or rejection region

When $\mathrm{F} \geq \mathrm{F}$ Calculate the table then Ho is rejected

When F Count $<\mathrm{F}$ table then Ho is accepted

4. $\mathrm{F}$ arithmetic $=6763>\mathrm{F}$ table $=2796$, then Ho is rejected

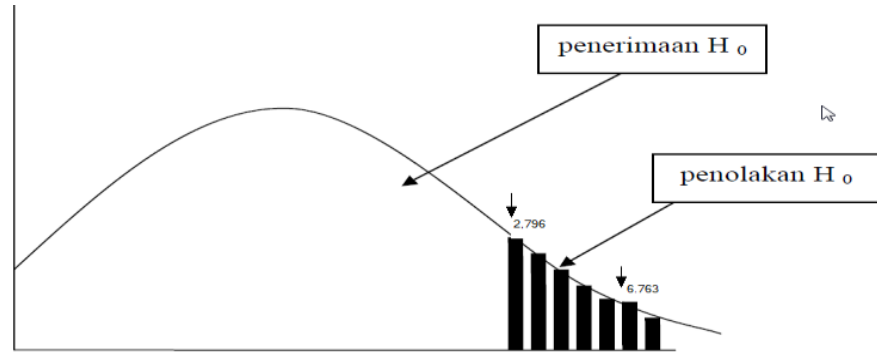

Figure 3 Regional Acceptance and Rejection Ho Test F.

5. Conclusion.

Since F count $(=6763)>\mathrm{F}$ table $(=2796)$ then Ho is rejected at the $5 \%$ significance level so that it can be concluded that all independent variables (variables Content, Design Variables, variables and variable Accessibility User Friendly) significantly affect the dependent variable $\mathrm{Y}$ (customer satisfaction). T test (Partial Test).

To test the hypothesis that use of t-test showed a partial effect of each independent variable on the dependent variable (not free). At this stage of testing the effect of independent variables contained in the model forms to determine whether the independent variable $(\mathrm{X})$ is in the partial models has a significant effect on the dependent variable (Y).

Calculation Table 3.Hasil t test

\begin{tabular}{|l|c|c|}
\hline \multicolumn{1}{|c|}{ Model Anova } & t hitung & $\mathrm{t}$ tabel \\
\hline Content (x1) & 0.657 & 2.048 \\
\hline Design (x2) & 0.649 & -2.048 \\
\hline Accessibility (x3) & 0.966 & 2.048 \\
\hline User Friendly (x4) & 0.833 & -2.048 \\
\hline
\end{tabular}

Sources: Appendix 3 (SPSS output).

Partial Test Variables Between Content (x1) for User Experience (Y)

For the $t$ test was used to test the hypothesis that shows the influence of the variable partially Content (x1) to variable User Satisfaction (Y).

hypothesis:

- Ho: $\beta 1=0$, meaning that the variable Content (X1) does not have a significant influence on User Satisfaction variable bound $(\mathrm{Y})$.

- H1: $\beta 1 \neq 0$, meaning that the variable Content $(\mathrm{X} 1)$ have a significant influence on the dependent variable User Satisfaction $(\mathrm{Y})$. 
- $\alpha=0.05 / 2=0025$ with $\mathrm{df}(\mathrm{k}, \mathrm{nk}-1)=23$ where $\mathrm{t}$ table $=2048$

$\cdot \mathrm{t}=0657$

- Testing:

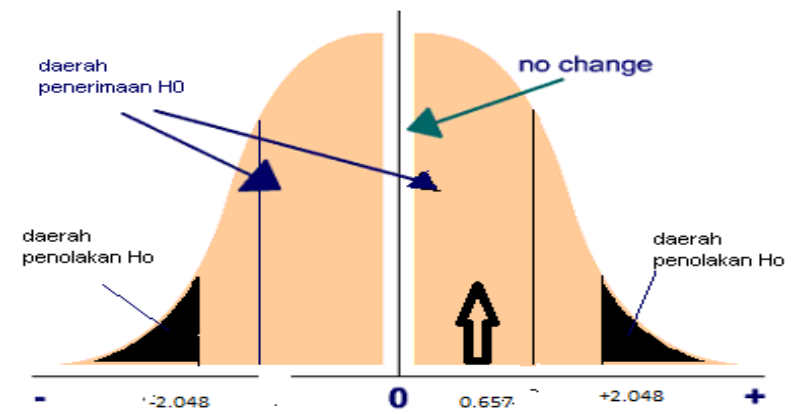

Figure 4 Regional Acceptance Or Rejection Criteria variables X1

Conclusion: Based on the output obtained by SPSS version $19 \mathrm{t}$ count for 0657 is smaller than t table for 2048. So Ho accepted at significance level of $5 \%$ so that the conclusion is partially Content variable does not affect the user's satisfaction. Partial Test Variables Between Design (x2) for User Experience (Y) For the $t$ test was used to test the hypothesis that shows the influence of the partial design variable (x2) to variable User Satisfaction (Y).. hypothesis:.

- Ho: $\beta 1=0$, meaning that variable Design (x2) does not have a significant influence on the dependent variable User Satisfaction $(\mathrm{Y})$..

- H1: $\beta 1 \neq 0$, meaning variable Design (x2) have a significant influence on the dependent variable User Satisfaction $(\mathrm{Y})$..

$\cdot \alpha=0.05 / 2=0025$ with $\mathrm{df}(\mathrm{k}, \mathrm{nk}-1)=23$ where $\mathrm{t}$ table $=2048 \cdot \cdot \mathrm{t}=-0649$.

- Testing:

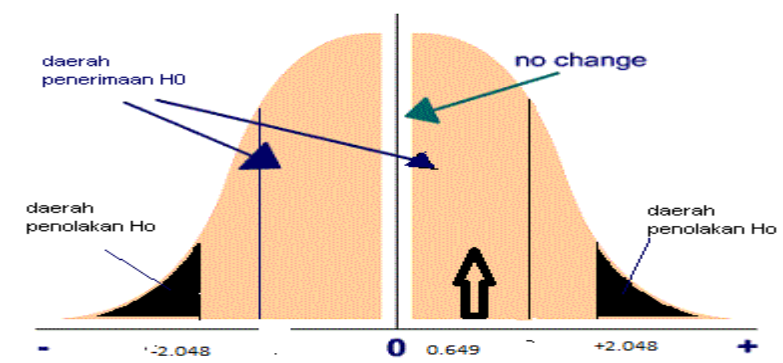

Figure 5.Regional Criteria Acceptance Or Rejection Variable X2.

Conclusion: Based on the output obtained by SPSS version $19 \mathrm{t}$ count for 0649 is smaller than $\mathrm{t}$ table for 2048 . So Ho accepted at $5 \%$ significance level that the partial conclusion Design variable does not affect the User Experience.

Partial Test Variables Between accessibility (x3) for User Experience (Y)

To test the hypothesis that use of t-test showed a partial effect accessibility variable (x3) for User Satisfaction variable (Y).

hypothesis:

- Ho: $\beta 1=0$, meaning that the variable accessibility (x3) does not have a significant influence on User

Satisfaction variable bound $(\mathrm{Y})$.

- H1: $\beta 1 \neq 0$, meaning accessibility variable (x3) have a significant influence on User Satisfaction variable bound (Y).

- $\alpha=0.05 / 2=0025$ with df $(\mathrm{k}, \mathrm{nk}-1)=23$ where $\mathrm{t}$ table $=2048$

$\cdot \mathrm{t}=0966$

- Testing:

New Sign in and click the star 


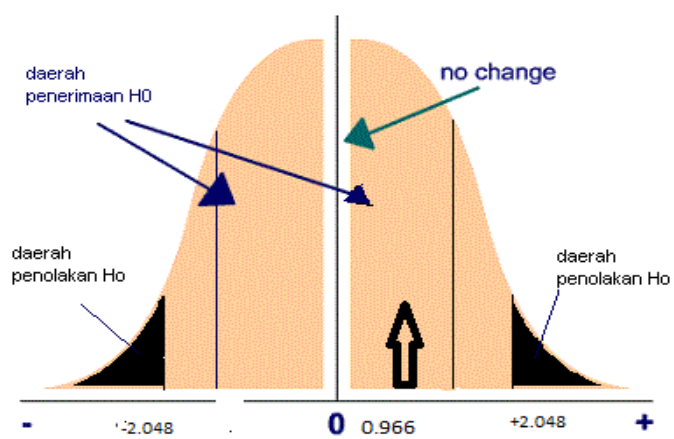

Figure 6. Regional Acceptance Or Rejection Criteria Variables X3.

Conclusion: Based on the output obtained by SPSS version $19 \mathrm{t}$ count for 0966 is smaller than $\mathrm{t}$ table for 2048 . So Ho accepted at $5 \%$ significance level that the partial conclusions Accessibility variable does not affect the user's satisfaction.

Partial Test Variables Between User Friendly (x4) for User Experience (Y)

For the $t$ test was used to test the hypothesis that shows the influence of partial variable User Friendly $(\mathrm{x} 4)$ to variable User Satisfaction (Y).

hypothesis:

- Ho: $\beta 1=0$, meaning that the variable User Friendly (x4) does not have a significant influence on User

Satisfaction variable bound $(\mathrm{Y})$.

- H1: $\beta 1 \neq 0$, meaning that the variable User Friendly (x4) have a significant influence on User Satisfaction variable bound $(\mathrm{Y})$.

- $\alpha=0.05 / 2=0025$ with df $(\mathrm{k}, \mathrm{nk}-1)=23$ where $\mathrm{t}$ table $=2048$

$\cdot \mathrm{t}=-0830$

- Testing:

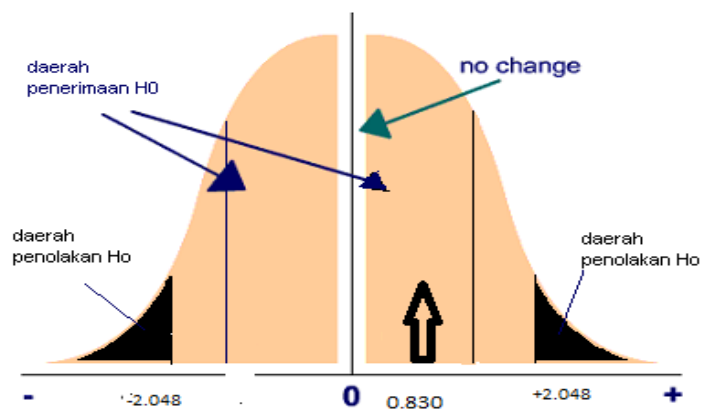

Figure 7. Regional Acceptance Or Rejection Criteria Variable X4.

Conclusion: Based on the output obtained by SPSS version $19 \mathrm{t}$ count for 0830 is smaller than $\mathrm{t}$ table for 2048 . So Ho accepted at $5 \%$ significance level that the partial conclusions User Friendly variable does not affect the user's satisfaction.

Partial Correlation Coefficient

Value of the partial correlation (r) indicates how close the relationship between the independent variables include variables Content (x1), Design (x2), Accessibility (x3), User Friendly (x4) on the dependent variable partial satisfaction of the users.

Table 4.Nilai Partial Correlation Coefficient

\begin{tabular}{|l|c|c|c|}
\hline \multicolumn{1}{|c|}{ Variabel } & $\mathrm{r}$ & $\mathrm{r}^{\wedge} 2$ & $\begin{array}{c}\text { Dalam } \\
\text { Prosentase }\end{array}$ \\
\hline Content (x1) & 0.136 & 0.0185 & $1.85 \%$ \\
\hline Design (x2) & 0.134 & 0.0179 & $1.79 \%$ \\
\hline Accessibility (x3) & 0.197 & 0.0388 & $3.88 \%$ \\
\hline User Friendly (x4) & 0.171 & 0.0292 & $2.92 \%$ \\
\hline
\end{tabular}

Sources: Appendix 3 (SPSS output).

Based on the data obtained is shown in Table 5. above, it appears that the value of the determinant coefficient ( $\mathrm{r}$ $\wedge 2$ ) is the biggest variable for Accessibility (X3) that is equal to 0.0388, which means partially Accessibility variable (x3) is the most dominant influence on user satisfaction, with a value of $3.88 \%$ percentage relationship . Then, a partial influence on user satisfaction is a variable User Friendly by 0.0292 , with a value of $2.92 \%$ 
percentage relationship., Effect least partially on user satisfaction is the design of 0.0179 and with a percentage of $1.79 \%$ relationship.

\section{Hypothesis Testing Results.}

The first hypothesis states that Content, Design, Accessibility and User Friendly affected simultaneously (together) to the satisfaction of users of the Website e-lelang.jatimprov East Java Provincial Government unsubstantiated. The magnitude of the correlation coefficient is 0735 . This value shows the four independent variables correlated positively for 0735 is extremely powerful / significant.

\section{Hypothesis 2 Testing Results.}

The second hypothesis states that the Content, Design, Accessibility and User Friendly partial effect (on their own) to the satisfaction of users of the Website e-lelang.jatimprov East Java Provincial Government can be described as follows..Content obtained on the variables t count for 0657 is smaller than $t$ table for 2048 . So Ho accepted at significance level of $5 \%$ so that the conclusion is partially variable has no effect on the Content User Experience. Design variables obtained at t count for 0649 is smaller than t table for 2048. So Ho accepted at $5 \%$ significance level that the partial conclusion Design variable does not affect the User Experience. Accessibility variables obtained at $t$ count for 0966 is smaller than t table for 2048. So Ho accepted at $5 \%$ significance level that the partial conclusions Accessibility variable does not affect the User Experience. User Friendly obtained in the variable $t$ count for 0830 is smaller than t table for 2048. So Ho accepted at significance level of $5 \%$ so that the conclusion is partially variable does not affect the User Friendly User Satisfaction. Discussion of Research Findings Based on the results of multiple linear regression analysis, Content, Design, Accessibility and User Friendly affect user satisfaction of e-lelang.jatimprov East Java Province interpretation of the results is as follows:.

Characteristics Influence On Simultaneous Judging from the value equation regression models were established, the figure simultaneous (combined) were positive, meaning that the combined value of the four variables (Content, Design, Accessibility and User Friendly) had a positive linear effect of the direction of the user satisfaction of e-lelang.jatimprov East Java Province. In other words, the quality characteristics of elelang.jatimprov East Java province affect user satisfaction. Furthermore, the variable Content, Design variables, variables Accessibility and User Friendly entirely variable (with a size 54.5\%) can explain variations Website User Experience e-lelang.jatimprov East Java Provincial Government. However, the value minus the variable coefficient and variable User Friendly Design needs to be explained as follows. If the Content enhanced variable it will lead to increased user satisfaction by 0539 , assuming other variables constant. If the enhanced design variable, it will lead to lower user satisfaction by 0217 , assuming other variables constant. If variables improved accessibility, it will lead to increased user satisfaction by 0414, assuming other variables constant. If the variable User Friendly improved, it will lead to lower user satisfaction by 0229, assuming other variables constant In Partial Characteristics Influence

a. Content obtained values to variables $t$ count for 0657 is smaller than $t$ table for 2048 , so the conclusion is partially at 5\% significance level variables unaffected Content for User Satisfaction. That is, there was no significant effect between variables Content for User Satisfaction when other variables are controlled constant. b. Design variable values obtained at $\mathrm{t}$ count for 0649 is smaller than $\mathrm{t}$ table for 2048 , so the conclusion is partially at 5\% significance level design variables are not affected to the user's satisfaction. That is, there was no significant effect between the User Experience Design variables when other variables are controlled constant.

c. Accessibility obtained values to variables t count for 0966 is smaller than t table for 2048, so the conclusion is partially at 5\% significance level variables unaffected accessibility to user satisfaction. That is, there was no significant effect between variables Accessibility for User Experience when other variables are controlled constant.

d. The value in the variable User Friendly obtained $t$ count for 0830 is smaller than $t$ table for 2048, so the conclusion is partially at $5 \%$ significance level variable User Friendly is not affected to the user satisfaction. That is, there was no significant effect between the variables User Friendly User Satisfaction when other variables are controlled constant.

\section{Conclusions And Recommendations.}

From the analysis using multiple linear regression in the previous chapter, it is concluded as follows: 1. Hypothesis one (H1) research that reads "Content, Design, Accessibility and User Friendly simultaneously have a significant effect on user satisfaction of e-lelang.jatimprov East Java Province" acceptable. It is based on F count $(=6763)>\mathrm{F}$ table $(=2796)$ then Ho is rejected at the $5 \%$ significance level so that it can be concluded that all the independent variables (Variable Content, Design Variables, Variable Accessibility, and Variable User Friendly) significantly the dependent variable Y (user satisfaction).. 
2. The second hypothesis (H2) research that reads "Partially each variable (Content, Design, Accessibility, User Friendly) a significant effect on customer satisfaction" is rejected. It is based from the test results that:.

- Content obtained values to variables $t$ count for 0657 is smaller than $t$ table for 2048 , so the conclusion is partially at 5\% significance level variables unaffected Content for User Satisfaction. - Design variables obtained value $t$ count for 0649 is smaller than $t$ table for 2048, so the conclusion is partially at 5\% significance level design variables are not affected to the user's satisfaction. - Accessibility obtained values to variables $t$ count for 0966 is smaller than $t$ table for 2048 , so the conclusion is partially at 5\% significance level variables are not affected accessibility to user satisfaction. - the value of the variable User Friendly 19 obtained $t$ count for 0830 is smaller than $t$ table for 2048 , so the conclusion is partially at 5\% significance level variable User Friendly is not affected to the user's satisfaction. From the regression equation models were established, it is concluded that:.

- If the variable Content enhanced it will lead to increased user satisfaction by 0539 , assuming other variables constant..

- If the design variables improved, it will lead to lower user satisfaction by 0217 , assuming other variables constant.

- If the variable improved accessibility, it will lead to increased user satisfaction by 0414 , assuming other variables constant.

- If the variable User Friendly improved, it will lead to lower user satisfaction by 0229 , assuming other variables constant..

Furthermore, it can also be concluded that the variable Content, Design variables, variables Accessibility and User Friendly with variable size can explain 54.5\% variation User Experience Website elelang.jatimprov East Java Provincial Government. Suggestion Based on the overall results and conclusions obtained, can be developed some suggestions for those interested in the study. The suggestions put forward are as follows:.

1. For the leadership and the bureaucracy at the Environmental Secretariat Building Administration Bureau of East Java Province, is expected to further increase the attention to these aspects of e-auction website Content and Accessibility aspects of it. From the research shows that these factors are a strong influence on user satisfaction. While the factors Design and User friendly relatively less influential..

2. 2. For further study, expected to be developed by extending the other independent variables. This is evident from the size of the $54.5 \%$ capacity to four variables in the model representation of user satisfaction, they provide $45.5 \%$ chance probability no outside influences Content, Design, Accessibility and User Friendly that can be studies.

\section{Daftar Pustaka}

[1]. Laudon, Kenneth C, 2005, Management Information System, Pearson Education Canada Inc.

[2]. Kotler, Philip, 1996, Manajemen Pemasaran Analisa Perencanaan, Implikasi, Jilid 1 dan 2, Prenhalindo, Jakarta

[3]. Gueritz, Andy, 2001, Understanding the benefit of e-procurement, Sixhills Consulting Ltd \& Author

[4]. David Cunliffe, 2002, Essential health psychology Essential psychology, blog.lumbungbuku.com/2012/02/buku-13.html

[5]. Harold koontz dan cyrill odonnell 1997, " Tugas kuliah " fungsi manajemen profesi pendidikan - [Also available on-line] http://www.apa.org/journals/amp/amp5391017.html and http://homenet.andrew.cmu ...

[6]. Morkes, J. \& Nielsen, J. (1997). "Concise, SCANNABLE, and....... users.aber.ac.uk/jpm/copaper/oet04.jmorgan1.docScribd. definisi.org/...harold-koontz-dan-cyrill-odonnell--99,

[7]. Buhalis.1996 , году отмечал.ru/ modules. Bce ... . ne stvara. mesto na kojem boravi ostavi čistim. ... Buhalis. Hudson. Beograd. Oxford. www.scribd.com/doc/56005034/Ekonomika-5-6-2008

[8]. Urban, Glen L, 2006 ... analysis, and decisions / Glen L. Urban, steven H. Star. Code: 658.802 URB a: library.um.ac.id/freecontents/index.php/search/ance.html.

[9]. Acme , 2003; buku panduan 2011free download intel desktop board dg41wv drivers for server; ptf.com/dell/dell+windows+7ou7670

[10]. Siwasak Pansukkum, 2010, Foreign Tourists' Perspectives On A Thailand Tourism Website, Master Project, Srinakharinwirot University.

[11]. Gonroos, C. 1984. A service quality model and its market implications. European Journal of Marketing, 18(4), 36-44.

[12]. Layla Hasan, 2008, Assessing the Quality of Web Sites, Jurnal Ilmiah, Loughborough University, UK.

[13]. Arikunto, Suharsini, 2006, Prosedur Penelitian Suatu Pendekatan Praktik, PT Rineka Cipta, Jakarta

[14]. Sekaran, U. (2000). Research methods for business: A skill building approach. New York: John Wiley \& Sons, Inc.

[15]. Sugiyono, 2004, Statistika Untuk Penelitian, CV. Alfabeta, Bandung

[16]. Sugiyono, 2009, Metode Penelitian Bisnis, CV. Alfabeta, Bandung

[17]. Singgih, 2010, Statistik Multivariat, Elex Media Komputindo, Jakarta 